\title{
Project specifics for the construction of a municipal solid waste treatment plant
}

\author{
Valery Grakhov ${ }^{10000-0002-4783-9044]}$, Ulyana Simakova $^{1}$, Sergei Mohnachev ${ }^{* 1}$, Yulia Kislyakova ${ }^{1}$, \\ and Evgeniya Grakhova ${ }^{1}$ \\ ${ }^{1}$ Kalashnikov Izhevsk State Technical University, 426069 Izhevsk, Russia
}

\begin{abstract}
Environmental trends and growing tendency to think about ecology play an important role in the development of modern industry. Significant role in this field takes a construction of plants for the processing of municipal solid waste, contributing to the neutralization of the harmful effects by different waste. This article represents development and stages of project implementation for the plant $\mathrm{OOO}$ «Kamskoye» that works with solid municipal waste in the city of Chaykovsky, Perm Territory. Investment efficiency of the construction of this facility was calculated. A model of interaction between business and government bodies, which regulate investment to waste disposal projects, is presented. The main structural elements of construction of a plant for processing municipal solid waste are shown. The project was developed using a public-private partnership model. The implementation of the project will ensure the production of secondary raw materials for its further use as an alternative source of heat and electricity generation, as well as the use of products necessary for the market in the production process. The main feature and advantage of the project is the possibility of using a principle "waste to income», which allows to provide your production with energy resources from reusable waste.

Keywords. Municipal solid waste, public-private partnership, waste disposal, investment, project implementation, prospective income, plant construction.
\end{abstract}

\section{Introduction}

The construction of industrial facilities is one of the most science- and labor-intensive activities in contemporary construction market. Growing tendency about ecological and environmental awareness, plays an important role in the development of modern industry. Significant role in this field takes a construction of plants for the processing of municipal solid waste, contributing to the neutralization of the harmful effects by different waste.

Researches of many authors are devoted to the problem of utilization and processing of municipal solid waste.

Chinese scientists Zhao X.-G., Jiang G.-W., Li A., Wang L [1] published a lot of researches about economic effect of transforming municipal solid waste into energy. Other Chinese scientists Xin-Gang Z., Gui-Wu J., Ang L., Yun L. discuss about technological

\footnotetext{
*Corresponding author: sa195909@yandex.ru
} 
issues, productivity, environmental safety and economic efficiency of building waste incineration plants in their country [2].

Researches of Jakubiak $M$ are devoted to development of methods for optimization of management of the sphere of solid waste management and improvement of the economic regulation mechanism. He discusses problems related to municipal waste management, using the example of Krakow (Poland). The analysis presented in the papers shows the municipal waste collection system and the main facilities for the management and recycling [3].

Burda V.Ye. assesses potential energy saving and the use of alternative energy sources in industry, through waste disposal using energy-saving equipment [4].

To support the idea of a sustainable environment, Fernández-Delgado M., Amo-Mateos E.D., Lucas S., García-Cubero M.T., Coca M. are considering extracting carbon from municipal mixed waste for fertilizer production [5].

Scientific publications of Italian and Turkish scientists, such as Cucchiella F., D'Adamo I., Rosa P., Özer B., Yay A.S.E., are devoted to social analysis and management of municipal plants for processing solid waste into an energy source [6-7].

Miranda M.L. and Hale B. conducted the research that provides insight into whether waste using plants can compete with fossil fuel ones [8].

Werther J. and Ogada T. in their scientific work «Sewage sludge combustion» considered the possibility of burning sewage sludge without harming the environment [9].

Japanese scientist Okuwaki A. explores the problem of processing raw materials from plastics in Japan [10].

It must be noted, that works of many authors are devoted to the problem of environmental pollution by plastic waste, as well as the problem of their disposal and recycling. Among them: Prata J.C., Patrício Silva A.L., da Costa J.P., Mouneyrac C., Walker T.R., Duarte A.C. [11], Rorrer N.A., Nicholson S., Carpenter A., Biddy M.J., Grundl N.J., Beckham G.T. [12], Jaiswal S., Sharma B., Shukla P. [13], Ashoor A.S., Kareem M.M., Al-Baiati M.N. [14], Ahmad A.F., Razali A.R., Razelan I.S.M., Jalil S.S.A., Noh M.S.M., Idris A.A. [15], Yuliusman I.T.R., Nasruddin Sanal A., Bernama A., Haris F. [16], Alqahtani F.K., Zafar I. [17], Agyeman S., Obeng-Ahenkora N.K., Assiamah S., Twumasi G. [18], Jassim A.K. [19], Awoyera P.O., Adesina A. [20].

According to the growing need to care for ecology and environmental protection, A.A. Dudolin. and Efremov A.N. in their scientific works, consider the problems, opportunities and prospects for the construction of an environmentally friendly waste processing plant [21].

The review allows us to conclude that modern science has identified extensive possibilities for processing solid municipal waste.

So, the purpose of this study is to substantiate the development and implementation of a project for plant construction for the processing of solid municipal waste, using the example of a plant in the city of Chaykovsky, Perm Territory, as well as creating a model of interaction between business, government bodies for investment management for the implementation of waste disposal projects.

\section{Methods}

The optimal combination of factors that determine success and achieved results in the form of built factories, structures and infrastructure is based on project management.

The plant will be located near the old landfill at the site of the IE Manakina T.A. (individual entrepreneur Manakina T.A.), which has been operating since January 2020. The best model for financing the project of plant construction is the BOLT one, which can be implemented using public-private partnership, through the following procedures and stages:

1) to hold a tender by the administration of the Perm Territory for the right to conclude an agreement on public-private partnership (PPP) between small and medium-sized 
businesses involved in the development and implementation of a project for the construction of a plant for the processing of solid municipal waste and the state. There are entities involved in concluding a public-private partnership agreement:

- IE Manakina T.A. - a small business, a tenant of land used for disposal purpose;

- OOO «Kamskoye» - an enterprise that won a tender for construction a plant for the processing of solid municipal waste, and also the developer of the project in the city of Chaykovsky;

- OOO «TransStroyExpert» - an enterprise that is a supplier of equipment for mechanical processing and disposal of solid municipal waste;

- Ministry of Construction of the Perm Territory is an institution that provides project financing;

- Ministry of Natural Resources and Environment of the Perm Territory - an institution that provides equipment financing for the automatic municipal solid waste processing;

2) development of project for a plant construction by specialists-designers of OOO «Kamskoye»;

3 ) construction of workshops (OOO «Kamskoye» acts as a main contractor):

- workshop for sorting solid municipal waste;

- workshop for mechanical processing of municipal solid waste;

- utilization workshop for solid municipal waste;

4) installation of electrical networks and water supply facility;

5) purchase, transportation and equipment installation for mechanical processing and disposal of solid municipal waste (equipment supplier - OOO «TransStroyExpert»);

6) beginning of the plant's operation and the processing of solid municipal waste;

7) creation of a new legal entity OOO «Eco-Monument» on the base of OOO «Kamskoye».

There are documents to formalize public-private partnership agreement:

- land lease contract;

- turnkey construction contract;

- documents confirming the purchase of equipment for the processing of municipal solid waste;

- enclosed documents.

OOO «Kamskoye», as a winner of the tender, develops the project, and builds a plant for processing solid municipal waste on a site leased by IE Manakina T.A., according to the public-private partnership agreement, as well as the rules of the BOLT model

After the construction is completed, all objects put into use, will be a property of OOO «Kamskoye». After that, it would be great solution to create a new legal entity - OOO «EcoMonument», to manage the plant. For the following object's sublease by a new legal entity, which will continue to operate, municipalities conclude lease agreements with a private partner.

Fig. 1 shows the BOLT model, which reflects an interaction of enterprises with government bodies according to public-private partnerships for the plant construction for the processing of solid municipal waste in Chaykovsky city.

During operation of the constructed plant, the decision may be revised and, a municipal unitary enterprise or other legal entity may become an operator of OOO «Eco-Monument».

In order to implement the proposed measures, a concept for the plant construction of processing solid municipal waste was developed, and it is advisable to plan organizational and managerial activities for that.

Table 1 describes main structural features of the plant construction project. 


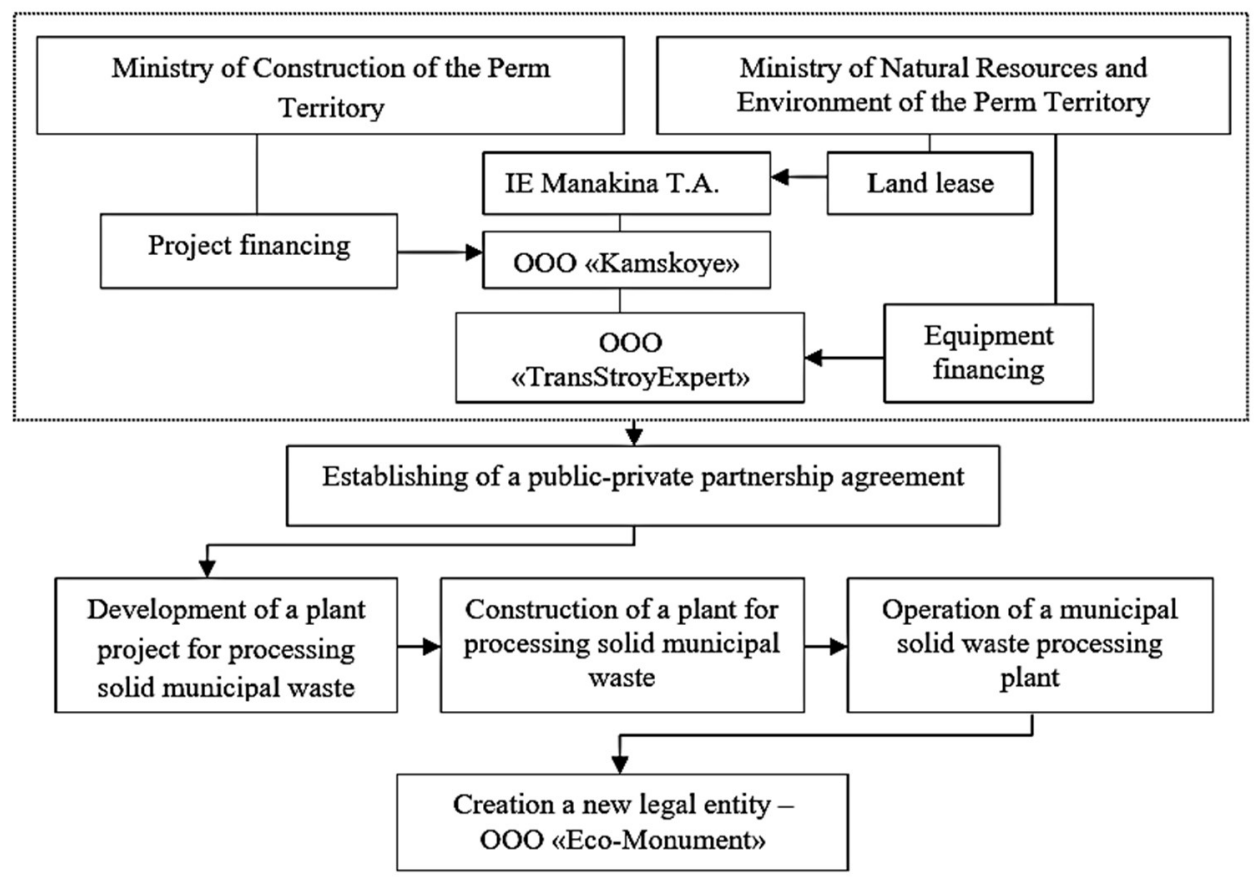

Fig. 1. A Model of interaction of enterprises with government bodies according to public-private partnerships.

Table 1. Project charter.

\begin{tabular}{|l|l|}
\hline Project title & $\begin{array}{l}\text { Construction of a plant for the processing of municipal solid waste in } \\
\text { Chaykovsky. }\end{array}$ \\
\hline Customer aim & $\begin{array}{l}\text { To create a technological process that ensures smooth processing and } \\
\text { disposal of municipal solid waste. }\end{array}$ \\
\hline Project aim & Smooth processing of municipal solid waste in Chaykovsky. \\
\hline Project results & $\begin{array}{l}\text { Neutralization of harmful effects on the environment by creating a } \\
\text { plant for the processing and disposal of solid municipal waste. }\end{array}$ \\
\hline $\begin{array}{l}\text { Success Factors of the } \\
\text { project }\end{array}$ & $\begin{array}{l}\text { The project includes: } \\
\text { - disposal } 60 \% \text { of solid municipal waste from the old site by the end } \\
\text { of } 2023 ; \\
\text { - disposal } 70 \% \text { of solid municipal waste from the old site by the end } \\
\text { of 2025; } \\
\text { - disposal } 80 \% \text { of new solid municipal waste. }\end{array}$ \\
\hline $\begin{array}{l}\text { Feasibility study of the } \\
\text { project }\end{array}$ & $\begin{array}{l}\text { Must be carried out to neutralize the harmful impact on the } \\
\text { environment, which is caused by the accumulated garbage at the old } \\
\text { landfill in Chaykovsky. }\end{array}$ \\
\hline Main participants & $\begin{array}{l}\text { Project manager: director of OOO «Kamskoye». } \\
\text { Project coordinator: Administrator of construction projects in OOO } \\
\text { «Kamskoye». }\end{array}$ \\
\hline Cost & 27808.75 thousand rubles \\
\hline Project period & From 01.02.2021 to 14.06.2021 \\
\hline
\end{tabular}

Project must be realized during 3 stages:

1) pre-project planning, coordination and approval of the project:

- preliminary preparation and planning of basic indicators of the project; 
- development and approval of design and design estimates;

- coordination of organizational issues with partners (IE Manakina T.A. and OOO «TransStroyExpert»);

- coordination of financial issues with authorized representatives of state institutions (Ministry of Construction of the Perm Territory, Ministry of Natural Resources and Environment of the Perm Territory).

2) construction of a plant for processing solid municipal waste:

- excavation and sand cushion preparation;

- laying of foundation;

- laying of prefabricated concrete blocks;

- perform masonry of checkpoint walls;

- perform masonry partitions;

- waterproofing walls;

- installation of engineering structures;

- installation of lentils above door and window;

- finishing work.

3) purchase, transportation and equipment installation for mechanical processing and disposal of solid municipal waste:

- equipment for sorting solid municipal waste;

- mobile sorting complex;

- press for polyethylene, metal and paper - 3 units;

- dryer.

An important factor of project management in construction is planning a work schedule, the best option for which is to use a network schedule.

Network schedule is an information-dynamic model of the production process, that shows the detailed and time sequence of work that must be performed to ensure the completion of all types of upcoming work no later than a specified time.

Fig. 2 shows the network schedule for the construction of a municipal solid waste processing plant.

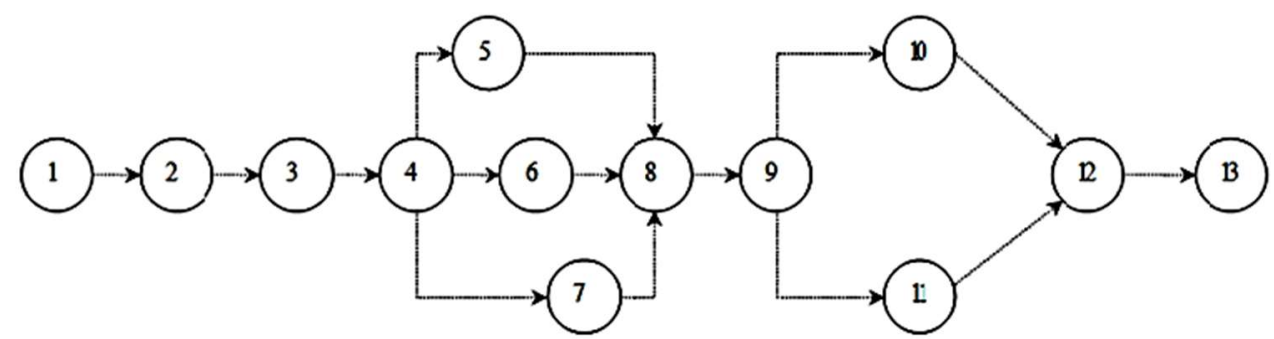

Designations:

1 - Project development; 2 - Excavation and sand cushion preparation; 3 - Laying of foundation; 4 - laying of prefabricated concrete blocks; 5 - Perform masonry of the plant; 6 - perform masonry partitions; 7 - Waterproofing walls; 8 - Roof installation; 9 - Finishing works and painting of walls; 10 - Installation of electrical networks; 11 - Installation of water supply and sewerage systems; 12 - Equipment installation; 13 - Launch of the plant.

Fig. 2. Network schedule for the construction of a municipal solid waste processing plant.

It should be noted that the processes of performing masonry of the plant, the laying of partitions and the waterproofing of the walls are carried out simultaneously, but with a slight shift in time, namely, the main and load-bearing walls are built firstly, while the construction of partitions is going on in parallel. Waterproofing walls carried out after the mortar has dried 
and performed by a team of bricklayers. Another tool for planning a plant construction schedule is the Gantt chart, which is one of the varieties of a network schedule, advantage of which is the graphical display of intervals on a time scale and the use of time intervals and work sequence in a graphical representation.

Fig. 3 shows a Gantt chart, that describes the sequence of work on the plant construction for the processing of solid municipal waste in Chaykovsky landfill.

The beginning of development the project for the construction of the plant is planned for March 9, 2021, the completion of construction and commissioning of the facility are planned for June 21-25, 2021.

\begin{tabular}{|c|c|c|c|c|c|c|c|c|c|c|c|c|c|c|c|c|}
\hline \multirow{3}{*}{ Name of works } & \multicolumn{16}{|c|}{2021} \\
\hline & \multicolumn{4}{|c|}{ March } & \multicolumn{4}{|c|}{ April } & \multicolumn{4}{|c|}{ May } & \multicolumn{4}{|c|}{ June } \\
\hline & 1 & 2 & 3 & 4 & 1 & 2 & 3 & 4 & 1 & 2 & 3 & 4 & 1 & 2 & 3 & 4 \\
\hline Project development & & & & & & & & & & & & & & & & \\
\hline Excavation and sand cushion preparation & & & & & & & & & & & & & & & & \\
\hline Laying of foundation & & & & & & & & & & & & & & & & \\
\hline Laying of prefabricated concrete blocks & & & & & & & & & & & & & & & & \\
\hline Perform masonry of the plant & & & & & & & & & & & & & & & & \\
\hline Perform masonry partitions & & & & & & & & & & & & & & & & \\
\hline Waterproofing walls & & & & & & & & & & & & & & & & \\
\hline Roof installation & & & & & & & & & & & & & & & & \\
\hline Painting of walls & & & & & & & & & & & & & & & & \\
\hline Installation of electrical networks & & & & & & & & & & & & & & & & \\
\hline $\begin{array}{l}\text { Installation of water supply and sewerage } \\
\text { systems }\end{array}$ & & & & & & & & & & & & & & & & \\
\hline Equipment installation & & & & & & & & & & & & & & & & \\
\hline Commissioning of the object & & & & & & & & & & & & & & & & \\
\hline
\end{tabular}

Fig. 3. Gantt chart for construction of a plant for processing solid municipal waste.

Delivery of materials should be organized prematurely and on March 25 all types of materials should be stored in the closed territory of the Chaykovsky landfill.

All construction works are performed by OOO «Kamskoye», which is a general contractor with the involvement of OOO «TransStroyExpert», which provides the sale, transportation, installation and equipment fixing for the processing of solid municipal waste. Performing masonry of the plant and partitions as well as walls waterproofing are realized simultaneously, but with a slight time shift. Main and load-bearing walls are built firstly while the construction of partitions is going on in parallel. Waterproofing walls carried out after the mortar has dried and performed by a team of bricklayers.

Fig. 4 shows directions for the implementation of the project for the construction of a plant in Chaykovsky.

The project for the construction of buildings, structures and roads of the plant for municipal solid treatment in Chaykovsky is being developed by the construction organization OOO «Kamskoye».

The accumulated waste of the old landfill is considered in the future as a secondary raw material that can be used as an alternative source of heat and electricity, as well as can be used in the production of products in response to customer future orders.

The result of the project can be such valuable products as rubber crumb and products from it (tiles, coatings), wood concrete, reinforced concrete products, secondary polymers (granulate, crushed material) and others. 


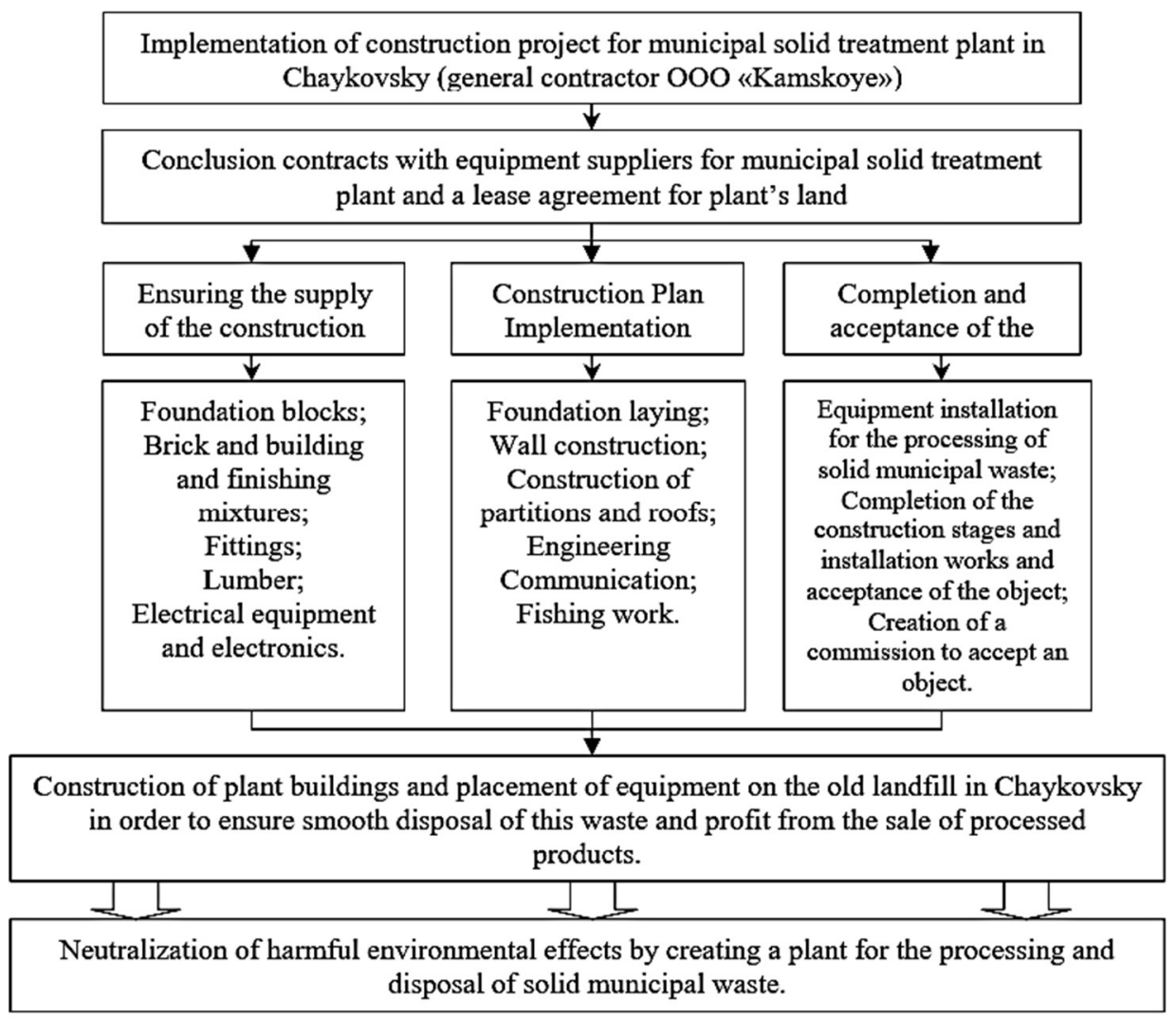

Fig. 4. Implementation of construction project for municipal solid treatment plant in Chaykovsky.

\section{Results and discussion}

An investment project was proposed aimed at financing the construction of the plant and the purchase and installation of equipment intended to processing and disposal of waste near to the old landfill.

The main costs are:

- costs for building materials, raw materials;

- construction and installation work of the plant's buildings;

- purchase of equipment and installations for processing and disposal of waste;

- registering a new legal entity and paperwork.

The total cost of materials will be 12716.20 thousand rubles.

The total cost of the purchase, transportation and installation of equipment will be 10740.5 thousand rubles.

Aggregated cost indicators are shown in Table 2.

Thus, the total cost of the plant construction will be 27808.75 thousand rubles.

Basic sources of income from processing and disposal of solid municipal waste are:

1) payments for the disposal of municipal solid waste;

2) sale of iron scrap;

3) gas sale obtained during processing solid municipal waste.

Table 3 shows prices of sold products and the volume of sales for the third and fourth quarters of 2021. 
Table 2. Estimated cost for municipal solid treatment plant in Chaykovsky.

\begin{tabular}{|l|c|}
\hline \multicolumn{1}{|c|}{ Types of costs } & Amount, thousand rubles \\
\hline \multicolumn{1}{|c|}{ Direct costs } \\
\hline Wage's contribution workers & 2619.95 \\
\hline Cash contributions (PF, FSI, FOMI) 30,2\% from payroll & 791.22 \\
\hline Materials & 12716.20 \\
\hline Machinery operations & 98.92 \\
\hline Depriciation & 12.36 \\
\hline Total direct costs & 16238.65 \\
\hline \multicolumn{2}{|c|}{ Overhead costs } \\
\hline Staff management salary & 592.90 \\
\hline Software and associated installation costs & 51.70 \\
\hline One-time reward for seniority & 132.14 \\
\hline Payment for additional vacations & 52.86 \\
\hline Total overhead costs & 829.60 \\
\hline Equipment & 10740.50 \\
\hline Total costs for construction of the plant & 27808.75 \\
\hline
\end{tabular}

Table 3. Revenue of municipal solid treatment plant in 2021.

\begin{tabular}{|l|c|c|c|}
\hline \multicolumn{1}{|c|}{ Source of income } & Price per unit, rub. & Quantity & $\begin{array}{c}\text { Amount } \\
\text { thousand rubles }\end{array}$ \\
\hline $\begin{array}{l}\text { Payments for the disposal of } \\
\text { municipal solid waste, } t\end{array}$ & 1073.9 & 36449.44 & 39143.05 \\
\hline Sale of iron scrap, $t$ & 6000 & 1438.12 & 8628.72 \\
\hline Gas sale, thousand $\mathrm{m}^{3}$ & 150 & 21814.19 & 3272.13 \\
\hline
\end{tabular}

Table 4. Dynamics of the planned income, operating costs and profits of municipal solid treatment plant in Chaykovsky during 2021-2026.

\begin{tabular}{|c|c|c|c|c|c|c|c|}
\hline $\begin{array}{c}\text { The name of } \\
\text { indicators }\end{array}$ & 2021 & 2022 & 2023 & 2024 & 2025 & 2026 & $\begin{array}{c}\text { Increasing, } \\
\%\end{array}$ \\
\hline \multicolumn{8}{|l|}{ Factory income } \\
\hline $\begin{array}{l}\text { Payments for the } \\
\text { disposal of municipal } \\
\text { solid waste }\end{array}$ & 39143 & 83199 & 94607 & 118933 & 149514 & 199837 & 410.53 \\
\hline Sale of iron scrap & 8629 & 18287 & 24083 & 34472 & 54164 & 62381 & 622.92 \\
\hline $\begin{array}{l}\text { Gas sale obtained } \\
\text { during processing solid } \\
\text { municipal waste }\end{array}$ & 3272 & 7190 & 8048 & 10117 & 12718 & 19168 & 485.82 \\
\hline Total plant income & 51044 & 108676 & 126738 & 163522 & 216396 & 281387 & 451.26 \\
\hline \multicolumn{8}{|l|}{ Transaction costs } \\
\hline $\begin{array}{l}\text { Recycling and disposal } \\
\text { of municipal solid waste }\end{array}$ & 37018 & 78682 & 89471 & 112476 & 141397 & 190330 & 414.16 \\
\hline Producing of iron scrap & 8149 & 17267 & 22892 & 32600 & 51224 & 58995 & 623.95 \\
\hline Gas production & 3094 & 6812 & 7611 & 9568 & 12028 & 18127 & 485.88 \\
\hline Total transaction costs & 48261 & 102761 & 119974 & 154645 & 204648 & 267452 & 454.18 \\
\hline $\begin{array}{l}\text { Payments for the } \\
\text { disposal of municipal } \\
\text { solid waste }\end{array}$ & 2125 & 4517 & 5136 & 6457 & 8117 & 9507 & 347.39 \\
\hline Sale of iron scrap & 480 & 1020 & 1191 & 1871 & 2941 & 3387 & 605.63 \\
\hline $\begin{array}{l}\text { Gas sale obtained } \\
\text { during processing solid } \\
\text { municipal waste }\end{array}$ & 178 & 378 & 437 & 549 & 690 & 1041 & 484.83 \\
\hline Total income & 2783 & 5915 & 6764 & 8877 & 11748 & 13934 & 400.68 \\
\hline
\end{tabular}


Calculation of the planned income is based on data obtained in settlements with the same population located in the Udmurt Republic (Izhevsk), in the Buryat Republic (Ulan-Ude), as well as on results of the Krasnoyarsk waste sorting plant (Krasnoyarsk) municipal solid treatment plant.

During a period from 2021 to 2026, the plant's profit from the processing of solid municipal waste will increase from 2783 thousand rubles to 13934 thousand rubles, that is, the increase will be $400.68 \%$ (or 5 times). The best option for attracting financial resources for the construction of the plant is to apply for a loan from Sberbank. The initial interest rate for investment lending is $16.7 \%$. An optimal interest rate of $10.0 \%$ was used because financing of the project implies the possibility of obtaining a loan on concessional terms. Concessional loans can be given due to government support program for OOO «Kamskoye», because the project is aimed at creating a plant for the processing of municipal solid waste, as well as the use of processed products for the production of heat energy.

Taking into account the costs of interests on loan payments, the amount of investment will be:

$$
27808+27808 \times 10 \%=30590 \text { thousand rubles. }
$$

The investment project involves a one-time investment in the amount of 30.590 thousand rubles at the beginning of 2021 (therefore discounting does not apply). The project will generate profit from the end of 2021, which will be 2783 thousand rubles for the third and fourth quarters.

We will evaluate the investment project. This value determines either net income or the net loss for investors. If funds are invested by parts over several years, the following formula is used to calculate NPV (1):

$$
\mathrm{NPV}=\sum \mathrm{C} F_{n} /(1+r)^{n}-\sum I_{J} /(1+r)^{J},
$$

where $n$ - number of income periods;

$j$ - the number of investment periods to the budget;

$C F$ - cash flow;

$I$ - investment.

Table 5. Data for assessing the investment performance.

\begin{tabular}{|l|c|c|c|}
\hline \multicolumn{1}{|c|}{ Indicator } & $\begin{array}{c}\text { Book value of expenses and } \\
\text { income, thousand rubles }\end{array}$ & $\begin{array}{c}\text { Discount rate in } \\
\text { case r }=0.1\end{array}$ & $\begin{array}{c}\text { Present value of } \\
\text { costs and incomes } \\
\text { for the project, } \\
\text { thousand rubles }\end{array}$ \\
\hline $\begin{array}{l}\text { Project's investment, } \\
\text { thousand rubles }\end{array}$ & & & \\
\hline 2021 investment, & 30590 & 1 & 30590 \\
\hline $\begin{array}{l}\text { Total income, } \\
\text { thousand rubles }\end{array}$ & 30590 & & 30590 \\
\hline $\begin{array}{l}\text { Project's } \\
\text { thousand rubles }\end{array}$ & & & \\
\hline 2021 2783 & 0.909 & 2530 \\
\hline 2022 & 5915 & 0.826 & 4888 \\
\hline 2023 & 6764 & 0.683 & 5082 \\
\hline 2024 & 8877 & 0.621 & 7295 \\
\hline 2025 & 11748 & 0.564 & 7866 \\
\hline 2026 & 13934 & & 33723 \\
\hline $\begin{array}{l}\text { Total income from the } \\
\text { project, thousand rubles }\end{array}$ & 50021 & & 3134 \\
\hline NPV, thousand rubles & & & \\
\hline
\end{tabular}


According to results, construction project for municipal solid treatment plant, will ensure the net income (after taxes) in the amount of 50021 thousand rubles at the end of 2026, that is, 6 years after the start of project financing.

Interest rate of $10.0 \%$ was used. The calculation of the profitability index based on discounting cash receipts is made according to the formula (2):

$$
\mathrm{PI}=\left[\sum C F_{n} /(1+r)^{n}\right] / \mathrm{I},
$$

Profitability index $=33723 / 30590=1.102$.

Profitability index $>1$, as a result, we can conclude that project is profitable.

The internal rate of return on investment is the value of the discount coefficient $r$, at which the NPV of the project is equal to zero.

IRR $=13.93 \%$ (Microsoft Excel)

ARR is calculated as (3):

$$
A R R=\frac{\bar{P}}{I}
$$

where $A R R$ - an indicator reflecting the profitability of a company, project and any investment object;

$\bar{P}$ - average net profit;

$I$ - initial investment amount.

$$
\mathrm{ARR}=((2530+4888+5082+6063+7295+7866) / 6) / 30590=0.1837,
$$

So, $\mathrm{ARR}=18.37 \%$.

Table 6 shows main parameters characterizing the level of investment efficiency.

Table 6. Main factors of investment project [22].

\begin{tabular}{|l|c|}
\hline \multicolumn{1}{|c|}{ Indicator } & Value \\
\hline Net present value, (NPV), thousand rubles & 3134 \\
\hline Profitability index, (PI) & 1.102 \\
\hline Internal rate of return (IRR), \% & 13.93 \\
\hline Accounting Rate of Return (ARR), \% & 18.37 \\
\hline The discounted payback period of the project, (DPB) & 5 years 7 months \\
\hline Simple payback period of the project (SPB) & 4 years 6 months \\
\hline
\end{tabular}

\section{Conclusions}

Investment project for municipal solid treatment plant in Chaykovsky is profitable and efficient.

Net present value will be 58841 thousand rubles; the project profitability index will be equal to 1.269; internal rate of return (IRR) will be 13.93\%; Accounting Rate of Return (ARR) will be $25.39 \%$, and the discounted payback period of the project (DPB) will be 6 years 3 months.

In general, for the period from 2022 to 2026 (2021 is not complete), the revenue of OOO «Eco-Monument» will increase from 51044 thousand rubles up to 281387 thousand rubles, that is, by $451.26 \%$; the profit of the plant will increase from 2783 thousand rubles up to 13934 thousand rubles, that is, an increase of $400.68 \%$, which indicates an increase of business activity and great opportunities for investment in the processing and disposal of solid municipal waste.

According to the results, it should be concluded that the proposed investment plan is feasible for implementation and must be approved.

So, the project for municipal solid treatment plant in Chaykovsky, Perm Territory, is costeffective and will contribute to solving ecological problems in Perm Territory, and ensuring the processing of solid municipal waste, both in the near future and in the long term [23]. 


\section{References}

1. X.G. Zhao, G.W. Jiang, A. Li, L. Wang. Economic analysis waste-to-energy industry in China, Waste Management 48, 604-618 (2016). DOI: 10.1016/j.wasman.2015.10.014.

2. Z. Xin-Gang, J. Gui-Wu, L. Ang, L. Yun. Technology, cost, a performance of waste-toenergy incineration industry in China, Renewable and Sustainable Energy Reviews 55, 115-130 (2016). DOI: 10.1016/j.rser.2015.10.137.

3. M. Jakubiak. Analysis of implementing sustainable municipal solid waste management. Krakow city case study, $14^{\text {th }}$ International multidisciplinary scientific geoconference SGEM Sofia, 17-24 (2014). DOI: 10.5593/SGEM2014/B52/S20.003.

4. V.Ye. Burda. The potential of energy saving and alternative energy using in the industry, Economic Journal - XXI 1 (2-1), 45-48 (2013).

5. M. Fernández-Delgado, E.D. Amo-Mateos, S. Lucas, M.T. García-Cubero, M. Coca. Recovery of organic carbon from municipal mixed waste compost for the production of fertilizers, Journal of Cleaner Production 265, 121805 (2020). DOI: 10.1016/j.jclepro.2020.121805.

6. B. Özer, A.S.E. Yay. Comparative life cycle analysis of municipal waste management systems: KiRKL Arely/Turkey study, Environmental Science and Pollution Research (2021). DOI: 10.1007/s11356-020-12247-0.

7. F. Cucchiella, I. D'Adamo, P. Rosa. Urban waste to energy (WTE) plants: social analysis, JP Journal of Heat and Mass Transfer 13 (3), 421-444 (2016). DOI: $10.17654 / \mathrm{MT} 013030421$.

8. M.L. Miranda, B. Hale. Waste not, want not: the private and social costs of waste-toenergy production, Energy Policy 25 (6), 587-600 (1997).

9. J. Werther, T. Ogada. Sewage sludge combustion, Progress in Energy and Combustion Science 25 (1), 55-116 (1999). DOI: 10.1016/S0360-1285(98)00020-3.

10. A. Okuwaki. Feedstock recycling of plastics in Japan, Polymer Degradation and Stability 85 (3), 981-988 (2004). DOI: 10.1016/j.polymdegradstab.2004.01.023.

11. J.C. Prata, A.L. Patricio Silva, J.P. da Costa, C. Mouneyrac, T.R. Walker, A.C. Duarte, Rocha-Santos. Solutions and integrated strategies for the control and mitigation of plastic and microplastic pollution, Int. Environ. Res. Public Health 16, 1-19 (2019). DOI: 10.3390/ijerph16132411.

12. N.A. Rorrer, S. Nicholson, A. Carpenter, M.J. Biddy, N.J. Grundl, G.T. Beckham Combining Reclaimed PET with Bio-based Monomers Enables Plastics Upcycling, Joule 3, 1006-27 (2019). DOI: 10.1016/j.joule.2019.01.018.

13. S. Jaiswal, B. Sharma, P. Shukla. Integrated approaches in microbial degradation of plastics, Environ. Technol. Innov. 17, 100567 (2020). DOI: 10.1016/j.eti.2019.100567.

14. A.S. Ashoor, M.M. Kareem, M.N. Al-Baiati. Improved asphalt binder using recycle polyethylene terephthalate polymer, IOP Conf. Ser. Mater. Sci., 571 (2019). DOI: 10.1088/1757-899X/571/1/012094.

15. A.F. Ahmad, A.R. Razali, I.S.M. Razelan, S.S.A. Jalil, M.S.M. Noh, A.A. Idris. Utilization of polyethylene terephthalate (PET) in bituminous mixture for improved performance of roads, IOP Conf. Ser. Mater. Sci., 203 (2017). DOI: 10.1088/1757899X/203/1/012005.

16. I.T.R. Yuliusman, Sanal A. Nasruddin, A. Bernama, F. Haris. Preparation of activated carbon from waste plastics polyethylene terephthalate as adsorbent in natural gas storage, J. Phys. Conf. Ser. 7, 1-6 (2017). DOI: 10.1088/1757-899X/176/1/012055.

17. F.K. Alqahtani, I. Zafar. Characterization of processed lightweight aggregate and its effect on physical properties of concrete, Constr. Build. Mater. 230, 116992 (2020). DOI: 10.1016/j.conbuildmat.2019.116992. 
18. S. Agyeman, N.K. Obeng-Ahenkora, S. Assiamah, G. Twumasi. Exploiting recycled plastic waste as an alternative binder for paving blocks production, Case Stud. Constr. Mater. 11, e00246 (2019). DOI: 10.1016/j.cscm.2019.e00246.

19. A.K. Jassim. Recycling of Polyethylene Waste to Produce Plastic Cement, Procedia Manuf. 8, 635-642 (2017). DOI: 10.1016/j.promfg.2017.02.081.

20. P.O. Awoyera, A. Adesina. Plastic wastes to construction products: Status, limitations and future perspective, Case Stud. Constr. Mater. 12, e00330 (2020). DOI: 10.1016/j.cscm.2020.e00330.

21. A.A. Dudolin, A.N. Efremov. Problems and prospects creating an environmentally friendly WTE plant, Journal of Physics: Conf. Series. $3^{\text {rd }}$ Conf. «Problems of Thermal Physics and Power Engineering» - Actual Issues of Thermal Power Engineering and Thermal Engineering, 042061 (2020). DOI: 10.1088/1742-6596/1683/4/042061.

22. M.A. Shtefan, J.M. Elizarova. Investment project efficiency and risk evaluation: an integrated approach, Business informatics 4 (46), 54-65 (2018). DOI: 10.17323/19980663.2018.4.54.65.

23. A.B. Chechulin, A.L. Kuznecov, V.P. Grahov, M.B. Perfil'eva. Communication and marketing technologies of territory promotion: forming professional market in Russia, Science and technique 19 (2), 125-129 (2020). DOI: 10.21122/2227-1031-2020-19-2-125-129. 